\title{
Phantom limb phenomenon as an example of body image distortion
}

\author{
Magdalena Razmus ${ }^{1} \mathrm{~A}, \mathrm{~B}, \mathrm{C}, \mathrm{D}, \mathrm{E}, \mathrm{F}$, Beata Daniluk ${ }_{\mathrm{C}, \mathrm{D}, \mathrm{E}}$, Piotr Markiewicz ${ }^{2,3}{ }_{\mathrm{D}, \mathrm{E}}$
}

\author{
${ }^{1}$ Institute of Psychology, Maria Curie - Sklodowska University, Lublin, Poland \\ ${ }^{2}$ The Faculty of Humanities, University of Warmia and Mazury in Olsztyn, Poland \\ ${ }^{3}$ The Regional Specialist Hospital in Olsztyn, Poland
}

\begin{abstract}
Introduction: The perception of one's own body, its mental representation, and emotional attitude to it are the components of socalled "body image" [1]. The aim of the research was to analyse phantom pain and non-painful phantom sensations as results of limb loss and to explain them in terms of body image distortion.

Material and method: Three methods were used in the study of 22 amputees ( 7 women and 15 men, between 43 and 76 years old, $M=61, S D=11.3$ ): (1) a clinical interview; (2) The Questionnaire of Body Experiencing after Limb Amputation; (3) modified version of The Pain Questionnaire based on The McGill Pain Questionnaire.

Results: The prevalence of phantom limb pain was 59\%. Some various non-painful phantom sensations after amputation were experienced by $77 \%$ of respondents. There was a statistically significant relationship between phantom pain and non-painful phantom sensations in a group of participants experiencing phantom limb phenomenon at the moment of the research.

Conclusions: Deformation of body image in the form of phantom pain and non-painful phantom sensations is a frequent experience after limb loss. We suggest that phantom limb is a form of out-of-date or inadequate body image as an effect of the brain activity trying to keep a kind of status quo. A co-occurrence of non-painful phantom sensations and phantom pain suggests that these both forms of post-amputation sensations may share neural mechanisms. Results indicate, that there exists somatosensory memory which may be manifested in similarities between pre- and post-amputation sensations.
\end{abstract}

Keywords: phantom limb phenomenon, phantom pain, body image, somatosensory memory

\section{Streszczenie}

Wprowadzenie: Na obraz ciała składa się percepcja własnego ciała, jego mentalna reprezentacja oraz stosunek emocjonalny wobec niego [1]. Celem badania była analiza bólu fantomowego i nie związanych z bólem doznań fantomowych jako rezultatu utraty kończyny oraz próba ich wyjaśnienia w kategoriach zniekształcenia obrazu ciała.

Materiał i metoda: W badaniu 22 osób po amputacjach kończyn (7 kobiet i 15 mężczyzn w wieku od 43 do 76 lat, $M=61, S D=$ 11.3) zastosowano trzy narzędzia: (1) wywiad kliniczny; (2) Kwestionariusz Doświadczania Własnego Ciała Przez Pacjenta Po Amputacji Kończyny; (3) zmodyfikowaną wersję Arkusza Doznań Bólowych, opartego na The McGill Pain Questionnaire.

Wyniki: Ból fantomowy wystąpił u 59\% uczestników badania, natomiast różnorodne doznania fantomowe nie związane z bólem były relacjonowane przez 77\% badanych po amputacjach kończyn. Stwierdzono statystycznie istotny związek między bólem fantomowym a doznaniami fantomowymi nie związanymi z bólem w grupie osób doświadczających zjawiska kończyny fantomowej w momencie badania.

Wnioski: Zniekształcenie obrazu ciała w postaci bólu fantomowego i nie związanych z bólem doznań fantomowych jest częstym doświadczeniem osób po utracie kończyny. Sugerujemy, że kończyna fantomowa jest formą nieaktualnego lub nieadekwatnego obrazu ciała, wynikającego z aktywności mózgu, który stara się zachować rodzaj status quo. Współwystępowanie doznań fantomowych nie związanych z bólem i bólu fantomowego wskazuje, że obie te formy doznań poamputacyjnych mają wspólne podłoże neuronalne. Wyniki sugerują, że istnieje pamięć somatosensoryczna, która przejawia się w podobieństwie doznań przed- i poamputacyjnych.

Słowa kluczowe: zjawisko kończyny fantomowej, ból fantomowy, obraz ciała, pamięć somatosensoryczna

\section{Introduction}

One's body is not only a material foundation of human existence, but also a particularly important source of stimuli to which we react. The ability of cognitive conceiving of own body, including its parts and boundaries is called somatognosis or "body sense" [2]. Cognitive psychology and neuropsychology (or broadly: cognitive neuroscience) in their analyses use mostly a term "body rep- resentation" to describe a mental model of a body which is created in human minds, and evidence its complexity and specificity $[3,4]$. It is suggested that body representation relies on multisensory data integration $[4,5]$, engages networks of numerous brain regions [6], and is a multidimensional concept within which various types of representations may be distinguished, depending on adopted criteria $[4,7,8]$. Taking into consideration a level of control 
and awareness of own body, body schema and body image are separately described [1]. Body schema is related mainly to unconscious integration of proprioceptive signals [9], especially in the context of motor activity and body position [1]. It is described in terms of a system of sensorimotor capacities, which create a dynamic (online) representation of spatial and biomechanical properties of one's body. Body schema is based on automatic schemas and operates typically beyond intentionality but it may be incorporated into volunteer and goal-directed performance $[1,3,4,10]$. Body image includes conscious perception and understanding of a body, as well as emotional attitude and behaviour towards it. This is a kind of abstract set of dispositions and states, in which one's body is an intentional object. Body image is usually referred to psychological dimension, while body schema applies mainly to the neurological one $[1,10]$. Although body schema and body image are distinct systems, they usually interact and influence each other during daily activities. On the other hand, they may be dissociated in case of neurological deficits or neuropsychological dysfunctions. For instance, intact body schema but distorted (or incomplete) body image are observed in unilateral neglect in personal space. Conversely, in sensory peripheral neuropathy, body image remains unimpaired, whereas body schema is disturbed or even abolished [1,3,11,12].

An example of body image malformation is phantom phenomenon which is defined as feeling pain or nonpainful sensations, which come from absent body parts or organs [13-15]. Phantom pain in patients after limb amputations is said to be a frequent phenomenon. Various publications give out different proportions of patients who experience this kind of pain, depending on sample characteristics and methods of assessment. The percentages range between $0.5 \%$ and $100 \%$ [13,16-18], what causes difficulties in drawing unambiguous conclusions about the incidence of phantom pain. There are many factors which are perceived to be associated with phantom pain occurrence and development, such as age, prosthetic use, time elapsed since amputation or sex [19]. Apart from its prevalence, phantom pain is discussed in terms of its frequency in a single patient, duration, intensity and qualitative descriptors [13,15-17,20-25]. Phantom pain may change its intensity or quality or even disappear over time [15]. Probability of phantom pain occurrence is enhanced by pre-amputation pain [16].

Similarly to phantom pain, proportion of patients reporting non-painful phantom sensations is diverse and depends, among others, on method of data gathering and time which passed from an amputation [16]. Most often it is stated that non-painful phantom sensations occur in from $70 \%$ to $100 \%$ of the questioned [26]. The sensations appear significantly more frequently in patients suffering from phantom pain than those who are free from this kind of pain $[16,26]$. It is also observed that they are more often of kinetic and kinaesthetic than exteroceptive nature [26]. Patients after limb amputations experience various numerous non-painful phantom sensations $[15,27,28]$. Pins and needles are the most often reported ones. Furthermore, patients relate to feel warmth or cold, pressure, itching and telescoping [15,18,29].

Patients after limb amputations constitute interesting, but still occasionally described part of population. Phantom sensations and phantom pain are quite seldom the subject of systematic studies and are investigated using rather inconsistent methodology, which causes difficulties in drawing coherent conclusions. Research on these phenomena seems important for at least two reasons. First, as studies suggest, phantom pain and nonpainful phantom sensations are quite common results of limb amputation. Knowledge on their properties and specificity, as well as identification of factors influencing their onset and modifying their features, induce methods of prevention and treatment in case of intense pain or bothersome non-painful sensations. Second, studies on phantom phenomena in amputees extend the insight into body-related data processing. They shed light on body experience and body representation in untypical bodily conditions, demonstrating how nervous system copes with a body part loss. Consequently, they help to comprehend mental model of one's body, its features, and mechanisms of formation.

This study aimed to describe consequences of a limb loss on body experience. The research was focused on incidence, properties, and dynamics of phantom pain and non-painful phantom sensations, as well as on relation between them after limb amputation. We expected, that both phantom pain and non-painful phantom sensations would be commonly reported by amputees, although percentage of subjects experiencing phantom phenomena at the moment of the research would be lower than the percentage of subjects experiencing phantom phenomena in the past (briefly after a limb loss). In line with previous studies, we anticipated the variety of qualities of phantom pain and non-painful phantom sensations. Moreover, we predicted that there would be a relationship between phantom pain and pre-amputation pain, as well as between non-painful phantom sensations and phantom pain. It was hypothesized that phantom limb phenomenon is an example of body image distortion and should be interpreted in terms of disturbed body representation.

\section{Method \\ Participants}

The research group consisted of 22 participants (7 women and 15 men) between 43 and 76 years old $(M=61, S D=11.3)$. Most respondents were the clients of 
The Public Institute of Orthopaedic Equipment or occupants of nursing homes in one of the big cities in Poland. The event which most frequently led to an amputation was vascular disease. All causes of amputations in the group are presented in Table 1 . Nineteen of the questioned $(86.4 \%)$ had one limb amputated, two persons two limbs, and one participant of the research lost four limbs. Detailed data on the level of amputation are enclosed in Table 2. The individuals differed in period of time after an amputation. The shortest was 4 months, while the longest amounted nearly 62 years $(M=10.6$ years, $S D=16.4$ ). There were no complications nor problems after amputation in 17 respondents (77\%). Five amputees $(23 \%)$ reported complications in the form of troublesome wound healing, growth of the amputated bone or symptoms of the primary disease, which had led to the amputation. In all these cases reamputations were necessary. Prostheses at the time of the research were used by 12 of the questioned (54.5\%), mainly irregularly, which made impossible to assess on average for how many hours a day prostheses were applied.

Table 1. Events leading to amputation in the group ( $\mathrm{N}=22)$

\begin{tabular}{|l|c|}
\hline Events & Number (\%) \\
\hline Vascular disease & $13(59.1 \%)$ \\
\hline Diabetes & $4(18.2 \%)$ \\
\hline Accident & $4(18.2 \%)$ \\
\hline Frostbite & $1(4.5 \%)$ \\
\hline
\end{tabular}

\section{Materials}

Three methods were used in the study: (1) a clinical interview, (2) The Questionnaire of Body Experience After Limb Amputation [30], (3) a modified version of The Pain Questionnaire which was based on The McGill Pain Questionnaire translated into Polish by K. Sedlak [31,32].

The interview was composed of two parts: questions concerning general information about participants of the study and questions referring to the amputation.

The Questionnaire of Body Experiencing after Limb Amputation has been worked out for the study due to lack of such methods in Polish [30]. It includes three parts: 1) painful sensations, 2) non-painful sensations, and 3) methods of coping with post-amputation sensations.
The Pain Questionnaire is a method based on The McGill Pain Questionnaire and is commonly used by anaesthetists involved in pain treatment. The Polish version of The Pain Questionnaire translated by K. Sedlak consists of 74 adjectives. An individual's task is to choose the adjectives, which best describe experienced pain [31,32]. Participants of a study are also asked to mark a location of pain on a scheme of human body [31]. For the study a modification of the questionnaire was applied: the first task was to mark pain location on an enlarged (in relation to the original) scheme of human body; afterwards a subject was asked to describe pain intensity on the 11-degree scale (originally 6-degree scale is used), where 0 means "no pain" and 10 stands for "the most intense pain one could imagine".

\section{Procedure}

Due to specificity of phantom phenomena, purposive sampling was applied. An including criterion was a fact of limb or limbs loss, at least at the level of foot in case of lower limb, and at the level of hand in case of upper limb. Furthermore, termination of hospitalisation and a phase of wound healing (about 3 months) was taken into account, which was supposed to eliminate problems and sensations proceeding from an injury. The research was anonymous and participants did not receive any reward. After the respondents gave informed consent, they were examined individually once. An assessment session lasted from 15 to 60 minutes, depending on quantity and variety of reported phantom sensations.

\section{Results \\ Phantom pain}

Phantom pain was reported by $59 \%$ of participants (13 persons), while $41 \%$ of them have never experienced this kind of pain. Phantom limb pain appeared to be a dynamic phenomenon: $23 \%$ of participants (3 persons, $N$ = 13) who have ever felt the pain, reported that it had passed off over time or as a result of treatment. Ten amputees, which is $77 \%$ of those who have ever gone through phantom pain $(N=13)$, have been experiencing it till the research. Eventually, at the moment of the study, phantom pain was reported by $45 \%$ of all respondents.

Table 2. Number of lost limbs and location of amputation $(\mathrm{N}=22)$

\begin{tabular}{|c|c|c|c|c|c|c|c|}
\hline Number of amputated limbs & \multicolumn{4}{|c|}{ One limb } & \multicolumn{2}{|c|}{ Two limbs } & \multirow{3}{*}{ Four limbs } \\
\hline Amputated limb & \multicolumn{2}{|c|}{ Lower } & \multicolumn{2}{|c|}{ Upper } & Upper & Lower & \\
\hline Side of amputation & Left & Right & Left & Right & & & \\
\hline $\begin{array}{l}\text { Number and percentage of } \\
\text { subjects }\end{array}$ & $\begin{array}{l}9 \\
41 \% \\
\end{array}$ & $\begin{array}{l}9 \\
41 \% \\
\end{array}$ & - & $\begin{array}{l}1 \\
4.5 \% \\
\end{array}$ & - & $\begin{array}{l}2 \\
9.1 \% \\
\end{array}$ & $\begin{array}{l}1 \\
4.5 \% \\
\end{array}$ \\
\hline $\begin{array}{l}\text { Level of amputation (number } \\
\text { of subjects) }\end{array}$ & $\begin{array}{l}\text { below } \\
\text { above }\end{array}$ & (5) & & $\begin{array}{l}\text { above } \\
\text { elbow (1) }\end{array}$ & & $\begin{array}{l}\text { below knee (1- } \\
\text { right side) } \\
\text { above knee (1- } \\
\text { both sides, } 1 \text { left } \\
\text { side) }\end{array}$ & $\begin{array}{l}\text { upper limbs: above } \\
\text { elbow } \\
\text { left lower limb: above } \\
\text { knee } \\
\text { right lower limb: } \\
\text { the level of knee }\end{array}$ \\
\hline Total \% & \multicolumn{2}{|c|}{$86.4 \%$} & & & \multicolumn{2}{|l|}{$9.1 \%$} & $4.5 \%$ \\
\hline
\end{tabular}


Average intensity of phantom pain determined on 11-degree scale by a current pain intensity index was 5.7 $(S D=2.24, \min .=2, \max .=10)$. In the study phantom pain was predominantly described as penetrating $170 \%$ of questioned), tiring and nagging (60\% in each case). The most frequent word descriptors chosen to characterise phantom pain are presented in Table 3 .

Table 3. The most frequent word descriptors chosen to characterise phantom pain $(\mathrm{N}=10$; multiple choice was possible)

\begin{tabular}{|l|l|}
\hline Pain quality & Number and percentage of subjects \\
\hline Penetrating & $7(70 \%)$ \\
\hline $\begin{array}{l}\text { Tiring } \\
\text { Nagging }\end{array}$ & $6(60 \%)$ \\
\hline $\begin{array}{l}\text { Stabbing } \\
\text { Tingling } \\
\text { Radiating }\end{array}$ & $5(50 \%)$ \\
\hline $\begin{array}{l}\text { Scalding } \\
\text { Annoying } \\
\text { Troublesome }\end{array}$ & $4(40 \%)$ \\
\hline $\begin{array}{l}\text { Vibrating } \\
\text { Tugging }\end{array}$ & $3(30 \%)$ \\
\hline $\begin{array}{l}\text { Pulsing } \\
\text { Pulling }\end{array}$ & $2(20 \%)$ \\
\hline
\end{tabular}

\section{Non-painful phantom sensations}

In the present study, non-painful phantom sensations were more frequent than phantom pain. At the moment of the research they were reported by $68 \%$ of participants who still had an impression of possessing a limb, although it had been amputated. However, a percentage of amputees who have ever experienced non-painful phantom sensations was higher. Similarly to phantom pain, non-painful phantom sensations receded in $9 \%$ of the respondents. In the examined group $23 \%$ of participants have never experienced non-painful phantom sensations. A great variety of non-painful sensations was observed in the group (see Table 4).

Table 4. The number and percentage of subjects experiencing different qualities of phantom sensations $(\mathrm{N}=15$ multiple choice was possible)

\begin{tabular}{|l|c|}
\hline $\begin{array}{l}\text { Non-painful } \\
\text { phantom sensations }\end{array}$ & Number (\%) \\
\hline Ability to move & $13(87 \%)$ \\
\hline Itching & $12(80 \%)$ \\
\hline Pins and needles & $11(73 \%)$ \\
\hline Going numb & $7(47 \%)$ \\
\hline Warmth & $6(40 \%)$ \\
\hline Increased muscle tone & $6(40 \%)$ \\
\hline Cold & $3(20 \%)$ \\
\hline Phantom limb fatigue & $1(7 \%)$ \\
\hline
\end{tabular}

The sensations did not appear individually, but many amputees experienced several sensations simultaneously (e.g., itching, tingling and warmth). An impression of "moving" phantom limb was notified the most frequently. A lot of participants reported that they could move it intentionally (e.g. stretch and crook a limb or move fingers), automatically and unconsciously (e.g. attempting to walk or jumping out of bed to answer the phone), and habitually (wagging the leg while talking with a researcher). Some amputees reported pins and needles, itching, tingling, feeling of altered temperature of phantom limb described as warmth or cold, and feeling of increased muscle tone, especially while walking. Furthermore, untypical phantom sensations were observed in the group. Some subjects reported that a limb was altered in relation to its pre-amputation state. With regard to length, position or features it differed from "original" (pre-amputation) body part. Two amputees reported a phenomenon of telescoping, in which a phantom limb becomes gradually shorter, whereas no amputee observed a sensation of lengthening or stretching limb beyond its original size. Four participants of the study had an impression of possessing a limb which was able to penetrate through objects. Three amputees reported that their limbs or their parts were crooked and it was impossible to stretch them. One person experienced phantom limb paralysis and another one reported that his phantom fists were clenched.

\section{Factors associated with phantom pain and non- painful phantom sensations}

Inquiring into mechanisms of phantom pain onset and persistence, an analysis of co-occurrence of phantom pain and pre-amputation pain was conducted. In the group of participants who had experienced preamputation pain as a result of long-lasting disease process prior to amputation, $71.4 \%$ had ever reported phantom pain, whereas $37.5 \%$ were free from preamputation pain but had ever experienced phantom pain. Among participants who suffered from phantom pain at the moment of the study, the proportions of respondents with and without pre-amputation pain amounted to $50 \%$ and $37.5 \%$ respectively. The analysis did not indicate statistically significant differences between incidence of phantom pain felt both ever $(p=$ .068 ) and at the moment of the study ( $p=.281)$ in groups of subjects with and without pre-amputation pain. An analysis of relationship between phantom pain and non-painful phantom sensations experienced ever and currently (at the moment of the research) was also performed. There was no statistically significant association in a group of participants who had ever experienced phantom limb phenomenon $\left(\chi^{2}=1.08, p>.05\right)$, while such relation was observed in subjects reporting phantom pain and non-painful phantom sensations at the moment of the research $\left(\chi^{2}=4.09, p<.05\right)$. 


\section{Discussion}

The aim of the research was a qualitative and quantitative analysis of sensations related by amputees in terms of phantom pain and non-painful phantom sensations. Describing phantom limb phenomenon, we focused on two time parameters: phantom sensations which occurred in any moment after amputation (whenever) and phantom sensations which were experienced at the moment of the research (currently). An attempt to identify relationships between phantom pain and non-painful phantom sensations, as well as association between preamputation and phantom pain was also undertaken.

Considering phantom pain, it was quite common consequence of a limb loss in the participants of the study, which is in line with previous reports $[13,16,17]$. In some individuals phantom pain receded spontaneously or as a result of pharmacotherapy. On the one hand, the result suggests that phantom pain is a dynamic phenomenon which may disappear or change its intensity or quality across time [15]. On the other hand, it corroborates the possibility to reduce painful phantom sensations with medication, as shown in the literature [20,31]. In the study, phantom pain was predominantly characterised by the questioned as penetrating, tiring and nagging, although its average intensity reached the level of moderate pain. The data are similar to results reported in the literature, where mean intensity amounts 5 points on 0 to 10 scale [13]. Searching for explanations of phantom pain origins, it was hypothesized that pre-amputation pain is a kind of risk factor for pain located subsequently in phantom limb. Sensations connected with original disease process, experienced even briefly before amputation, may later manifest themselves as phantom pain. Interestingly, it is pre-amputation pain intensity, not its duration, especially vital. In the present study phantom pain occurred whenever after amputation in more participants with preamputation pain than in those who had not experienced pain before limb loss. The disparity, although within the limit of statistical significance, supports a tendency described in the literature and corroborates Katz and Melzack's concept of so called somatosensory pain memory [20,33,34]. An occurrence of phantom pain, which is similar in its quality and intensity to pre-amputation pain, might be explained in terms of nervous system's ability to store in neurons and synaptic junctions memory of pain which had appeared before limb loss. Noteworthy, patients who had experienced pain before amputation, more often reported phantom pain whenever in the past, while in a lesser degree, this tendency applied to phantom pain felt at the moment of the research. The obtained results are consistent with results of Kooijman et al. [16] who stated that pre-amputation pain is a risk factor only for phantom pain immediately or briefly after amputation, but not for long-lasting pain.
More frequently than phantom pain, non-painful phantom sensations were reported by participants, what is consistent with previous studies [26]. Similarly to phantom pain, non-painful phantom sensations receded across time in some individuals. The most frequent non-painful phantom sensation was ability to "move" phantom limb, both intentionally and habitually. There existed the cooccurrence of various non-painful phantom sensations, where an ability to move phantom limb combined with itching accompanied by pins and needles were the most frequently reported. In the study there were also people experiencing untypical phantom sensations connected with body image alterations. Two respondents reported telescoping phenomenon, which is a gradual phantom limb shortening. Some participants of the research reported an impression of possessing a limb, but simultaneously the limb was able to penetrate through objects. One person experienced phantom limb paralysis and it is noteworthy, that before amputation the person had experienced fingers' tendons rupture and had lost an ability to move those fingers. It may suggest, that not only somatosensory pain memory is possible, but also that memory of non-painful phantom sensations may exist. If the sensations are somehow unnatural, intense and long-lasting, they might be encoded in nervous system and then occur as a symptom of phantom limb phenomenon [28]. There were also participants who tried to walk or jumped out of their bed or chair, because they "forgot that their limb (or limbs) had been amputated. This behaviour is consistent with a tendency to forget about the limb's absence which was described by Gallagher and Meltzoff [1]. Attempts to walk or stand up using two limbs, despite the lack of one of them, are expression of preserved motor schema which is coded in nervous system. They indicate a highly automated nature of walking with a slight susceptibility of the motor schema to changes in a direct post-amputation period. Modification of this encoded pattern proceeds gradually, as signals and pieces of information coming from various sources (various body parts) are integrated.

Analysis of phantom pain and non-painful phantom sensations co-occurrence did not prove statistical significance in group of subjects experiencing phantom pain whenever after amputation. Considering currently experienced phantom pain, the analysis showed a relation between phantom pain and non-painful phantom sensations. It suggests that non-painful phantom sensations appear considerably more often in people experiencing phantom pain and when there is no pain, they may have a transient nature. The observations support results of the previous studies, in which non-painful phantom sensations occurred more frequently in patients who suffered from phantom pain than in those who were free from this kind of pain $[16,26]$. It was also observed that the sensations 
were more often of kinetic and kinaesthetic than exteroceptive nature, as demonstrated in the literature [26].

There exists a disagreement, if phantom limb is body image or body schema distortion [1]. More convincing are the arguments for treating phantom limb as a disturbance of body image, which includes perceptive experiencing of own body, its mental representation and emotional attitude towards the body. Two latter elements form a set of beliefs or attitudes and have a nature of intentional processes $[1,10]$. Phantom phenomenon is accompanied by vivid feeling of a limb presence, its attachment to a body and certain emotional attitude towards experienced sensations. Moreover, observations suggest that patients reporting ability to move the phantom limb, do it intentionally and plan a course of the activity. According to their relations, such movement requires focussing on a limb or "imagining" the movement. It gives a ground for treating phantom limb phenomenon as an element of body image, containing not only sensory properties of such experiences, but also engaging conceptual qualities, i.e. imagination, intention, and plan of action. Therefore, the phenomenon recruits higher order processes and mental representations [29]. Phantom sensations, according to Melzack [1], involve "perceptual awareness", that is why they should be considered as body image malformation.

Taken together, the study extends the knowledge on phantom limb phenomenon in individuals after limb/limbs amputation by describing incidence and properties of phantom pain and non-painful phantom sensations, and interpreting them in terms of body image distortion. However, despite this contribution, it has its limitations. First, the sample was not large and consisted significantly more men than women. Second, the group was diverse in terms of amputation characteristics. It would be advisable, in our opinion, to revise the study in more homogeneous group and to control amputation variables more carefully. Third, the research had exploratory nature and used only self-reports. The study design was simple and did not allow to manipulate variables. Last, we did not control state of health (e.g., neurologic deficits) and neuropsychological functioning of the subjects. We find it beneficial to apply in the future studies some additional variables and measures which would expand possibility to investigate phantom limb phenomenon mechanisms and interpret it from neuropsychological point of view.

\section{Conflict of interest}

The authors have declared no conflict of interest.

\section{References}

1. Gallagher S, Meltzoff AN. The earliest sense of self and others: Merleau-Ponty and recent developmental studies. Philos. Psychol. 1996;9:213-36.
2. Kułakowska Z. Wczesne uszkodzenie dojrzewającego mózgu. Od neurofizjologii do rehabilitacji. Lublin: Wydawnictwo Folium; 2003.

3. Gallagher S, Cole J. Body image and body schema in a deafferented subject. J. Mind Behav. 1995;16:369-89.

4. Giummarra MJ, Gibson SJ, Georgiou-Karistianis N, Bradshaw JL. Mechanisms underlying embodiment, disembodiment and loss of embodiment. Neurosci. Biobehav. Rev. 2008;32:143-60.

5. Jeannerod M. Visual and action cues contribute to the self-other distinction. Nat. Neurosci. 2004;7:422-3.

6. Churchland PS. Self-representation in nervous systems. Science. 2002;296:308-10.

7. Sirigu A, Grafman J, Bressler K, Sunderland T. Multiple representations contribute to body knowledge processing. Evidence from a case of autotopagnosia. Brain J. Neurol. 1991;114 (Pt 1B):629-42.

8. Schwoebel J, Coslett HB. Evidence for multiple, distinct representations of the human body. J. Cogn. Neurosci. 2005;17:543-53.

9. Maravita A, Iriki A. Tools for the body (schema). Trends Cogn. Sci. 2004;8:79-86.

10. Gallagher S. Body schema and intentionality. In: Bermúdez JL, Eilan N, Marcel A, editors. Body Self. Cambridge MA: The MIT Press; 2001. p. 225-44.

11. Gallgher S. How the body shapes the mind. New York: Oxford University Press; 2005

12. Cole J, Paillard J. Living without touch and peripheral information about body position and movement: Studies with deafferented subjects. In: Bermúdez JL, Eilan N, Marcel A, editors. Body Self. Cambridge MA: The MIT Press; 2001. p. 245-66.

13. Ehde DM, Czerniecki JM, Smith DG, Campbell KM, Edwards WT, Jensen MP, et al. Chronic phantom sensations, phantom pain, residual limb pain, and other regional pain after lower limb amputation. Arch. Phys. Med. Rehabil. 2000;81:1039-44.

14. Goldenberg G. Disorders of body perception. In: Farah MJ, Feinberg TE, editors. Patient-Based Approaches Cogn. Neurosci. Cambridge MA: The MIT Press; 2000. p. 107-14.

15. Hill A. Phantom limb pain: a review of the literature on attributes and potential mechanisms. J. Pain Symptom Manage. 1999;17:125-42.

16. Kooijman CM, Dijkstra PU, Geertzen JH, Elzinga A, van der Schans CP. Phantom pain and phantom sensations in upper limb amputees: an epidemiological study. Pain. 2000;87:33-41.

17. Nikolajsen L, Jensen TS. Phantom limb pain. Br. J. Anaesth. 2001;87:107-16.

18. Wolff A, Vanduynhoven E, van Kleef M, Huygen F, Pope JE, Mekhail N. 21. Phantom Pain. Pain Pract. 2011;11:403-13.

19. Bosmans JC, Geertzen JHB, Post WJ, van der Schans CP, Dijkstra PU. Factors associated with phantom limb pain: a 31/2-year prospective study. Clin. Rehabil. 2010;24:444-53.

20. Flor H. Phantom-limb pain: characteristics, causes, and treatment. Lancet Neurol. 2002;1:182-9.

21. Flor H. Phantom limb pain. In: Ramachandran VS, editor. Encycl. Hum. Brain. New York: Elsevier Science; 2002. p. 831-41.

22. Melzack R. From the gate to the neuromatrix. Pain. 1999;Suppl 6:S121-6.

23. Schott GD. Delayed onset and resolution of pain: some observations and implications. Brain J. Neurol. 2001;124:1067-76.

24. Whyte AS, Niven CA. Psychological distress in amputees with phantom limb pain. J. Pain Symptom Manage. 2001;22:938-46.

25. Whyte AS, Niven CA. Variation in phantom limb pain: results of a diary study. J. Pain Symptom Manage. 2001;22:947-53.

26. Montoya P, Larbig W, Grulke N, Flor H, Taub E, Birbaumer N. The relationship of phantom limb pain to other phantom limb phenomena in upper extremity amputees. Pain. 1997;72:87-93. 
27. Hsu E, Cohen SP. Postamputation pain: epidemiology, mechanisms, and treatment. J. Pain Res. 2013;6:121-36.

28. Ramachandran VS, Levi L, Stone L, Rogers-Ramachandran D, McKinney R, Stalcup M, et al. Illusions of body image: What they reveal about human nature. In: Llinás R, Churchalnd PS, editors. Mind-Brain Contin. Sens. Process. Cambridge MA: The MIT Press; 1996. p. 29-61.

29. Giummarra MJ, Georgiou-Karistianis N, Nicholls MER, Gibson SJ, Chou M, Bradshaw JL. Corporeal awareness and proprioceptive sense of the phantom. Br. J. Psychol. 2010;101:791-808.

30. Gontarczyk M. Doświadczanie własnego ciała przez pacjentów po amputacjach kończyn [Unpublished master's thesis]. [Lublin]: Maria Curie-Sklodowska University; 2006.

31. Dobrogowski J, Kuś M, Sedlak K, Wordliczek J. Ból i jego leczenie. Warszawa: Springer PWN; 1996.

32. Melzack R. The McGill Pain Questionnaire: major properties and scoring methods. Pain. 1975;1:277-99.

33. Flor H, Nikolajsen L, Staehelin Jensen T. Phantom limb pain: a case of maladaptive CNS plasticity? Nat. Rev. Neurosci. 2006;7:873-81.
34. Li S, Melton DH, Li S. Tactile, thermal, and electrical thresholds in patients with and without phantom limb pain after traumatic lower limb amputation. J. Pain Res. 2015;8:169-74.

\section{Correspondence address}

Magdalena Razmus, Ph.D.

Institute of Psychology, Maria Curie-Sklodowska University,

Plac Litewski 5, 20-080 Lublin, Poland

e-mail: magdalena.razmus@gmail.com

Tel. No. 815376061

Otrzymano: 27.05.2017

Zrecenzowano: 28.06.2017

Przyjęto do druku: 30.06.2017 